\title{
SIXTEENTH CENTURY TURKISH INFLUENCE IN WESTERN INDONESIA
}

\author{
Anthony Reid
}

The existence of diplomatic and military relations between Ottoman Turkey and some Muslim states of Southeast Asia has been known for centuries. The Portuguese chroniclers, notably Couto and Pinto, kept the idea alive in the West; oral traditions and a few chronicles kept it more vividly before the imagination of the Atjehnese; and in Turkey there has been a revived interest in the connection since at least 1873. An attempt therefore seems overdue to seek greater precision on these remarkable events, by considering at least the most notable of the sources from the three sides.

For the peoples of Indonesia and Malaysia, the Raja Rum has figured as one of the great kings of the world since the earliest Muslim literature. Since the sixteenth century this title clearly referred to the Ottoman Sultan, the strongest of Muslim monarchs and heir presumptive to the dignity of the Caliphate. Long before the Ottoman rise, however, Persian and Turkish literature used Rum to designate the Byzantine, and occasionally also the Roman Empires. ${ }^{1}$ It is clear that the legendary greatness of this distant kingdom owed something to the lustre of all three imperial occupants of Constantinople.

Many traditions of Malaya and Sumatra, in particular, associate Raja Rum, the great king of the West, with Raja China, the great king of the East. A typical origin myth is that of Johor, as quoted by Marsden. ${ }^{2}$ Iskandar Dzul karnain (Alexander the Great) had three sons by the daughter of the King of the Ocean. After a contest between the three brothers in Singapore Straits, the eldest went to the West to become Raja Rum, the second East to become Raja China, while the third remained at Johor, to begin the later Minangkabau dynasty. Even as late as Marsden's own time in Sumatra (1771-9) the Sultan of Minangkabau styled himself younger brother of the rulers of Rum and China. ${ }^{3}$

A similar origin myth is that of Kedah, contained in the Hikayat Marong Mahawangsa. ${ }^{4}$ The story goes that Garuda, the bird of

1. Encyclopedia of Islam III, 1174-5.

2. The History of Sumatra 3rd Ed. (London, 1811), pp. 341-2.

3. Ibid. pp. 338-41. 


\section{TURKISH INFLUENCE IN WESTERN INDONESIA}

Vishnu, who inhabited the island Langkapuri, made a wager with Suleiman (Solomon - lord of the animal world in Muslim literature), that he could prevent the destined marriage between the son of Raja Rum and the daughter of Raja China. Garuda succeeded in capturing the Chinese princess and bringing her to Langkapuri, and then sank the fleet which was bringing the prince of Rum together with his escort, the hero Marong Mahawangsa. The prince, however, drifted to Langkapuri and there married the princess from China, bringing frustration to Garuda. Meanwhile Marong Mahawangsa established the kingdom of Langkasuka. Soon after he returned to Rum, leaving Langkasuka to his son, who was the progenitor of the dynasties of Siam (the eldest), Kedah, P'atani, and Perak.

Equally fanciful tales are current among the Gayo, who now inhabit the interior of Atjeh in Northwest Sumatra though they appear to have come from the coast. They relate that a young child of Raja Rum was conveyed to Sumatra, where the child was brought up by a local fisherman, and in time became the progenitor of the Gayo people. 5

The list of such traditions could certainly be lengthened. Suffice it to say that when first Ottoman Turkey emerged as a power in the Indian Ocean it became the focus of a considerable heritage of tradition about a mighty kingdom in the West.

Only in Atjeh, however, do we find written accounts of contact with Turkey which bear a historic character. The most reliable chronicle of sixteenth century Atjeh is the Bustanu's-Salatin, written in the Atjehnese capital by the Gujerati Nurud-din ar-Raniri in 1638. In his usual factual manner, Nurud-din ascribed the opening of relations with Turkey to the Atjehnese Sultan Alau'dDin Ri'ayat Shah al-Kahar (1537?-1571):

$\mathrm{He}$ it was who created the system of government of Atjeh Daru's-Salam and sent a mission to Sultan Rum, to the state of Istanbul, in order to strengthen the Muslim religion. The Sultan Rum sent various craftsmen and experts who knew how to make guns. It was at that time that the large guns were cast. It was also he who first built a fort at Atjeh

4. Siti Hawa Saleh, Hikayat Merang Mahawangsa (Unpublished M.A. Thesis, University of Malaya, 1966).

Abdullah b. Haji Musa Lubis (ed.), Kesah Raja Marong Maha Wangsa (Kuala Lumpur, 1965). R. O. Winstedt, 'The Kedah Annals', JMBRAS 16, 11 (1938), 31-5. C. Hooykaas, Over Maleise Literatuur 2nd Ed. (Leiden, 1947), pp. 91-4.

5. H. M. Zainuddin, Tarich Atjeh dan Nusantara (Medan, 1961), pp. 197-8. For another reference to Gayo origins see A. H. Hill (ed.) 'Hikayat Raja-Raja Pasai', JMBRAS 33, Pt. 2 (1960), p. 120. 


\section{TURKISH INFLUENGE IN WESTERN INDONESIA}

Daru's-Salam, and he who first fought all unbelievers, to the extent of going to attack Malacca in person. ${ }^{6}$

The most famous of the "large guns" to which Raniri referred was known to the Atjehnese as lada sa-chupak-one (bamboo) measure of pepper. It lay at the mouth of the Atjeh-river until taken to Holland in 1874, and still bears a Turkish star-motief along the barrel. ${ }^{\top}$ Most of the oral traditions which have been strongly preserved in Atjeh about a mission to Turkey are woven around this fine piece of artillery. At least one chronicle, the Atjehnese epic poem Hikayat Meukota Alam, ${ }^{8}$ has preserved this tradition in writing. It attributes the mission to Iskandar Muda (1607-36), the Atjehnese roi-soleil traditionally credited with many of the spectacular achievements of the early Sultanate. He decided to send an envoy to Istanbul with money for the support of the holy places, because the Sultan of Turkey was the greatest among Muslim rulers and had the care of the holy places. He sent three ships, laden with padi, beras and pepper respectively. But the crew had such difficulties that they only reached Istanbul after three years, by which time they had eaten all the rice, and sold most of the pepper to support themselves. Only sa-chupak lada remained. The envoys were mortified, but Sultan Rum was magnanimous, and sent them back in state with the great cannon, which he named himself. He also sent to Atjeh twelve pahlawans (war-leaders). These were so skilfull that they enabled Iskandar Muda to build the great fort of Atjeh, the palace, and even the famous Gunongan (more reliably credited to Iskandar Thani (1637-41)). Sultan Rum had advised Iskandar Muda to kill the pahlawans when they had finished their work. He was at first reluctant to do so, but the Turks finally alienated everybody by their arrogance, and were stoned to death. ${ }^{9}$

The story of the pahlawans appears to be a special touch of this poet, but in other respects the story is similar to those which have

6. Ia-lah yang meng'adakan segala isti'adat kerajaan Atjeh Daru's-Salam dan me. nyuroh utusan kapada Sultan Rum, ka-negeri Istanbul, kerana menegohkan ugama Islam. Maka di-kirim Sultan Rum daripada jenis utus dan pandai yang tahu menuang bedil. Maka pada zaman itu-lah di-tuang orang meriam yang besar2. Dan ia-lah yang pertama2 berbuat kota di-negeri Atjeh Daru's-Salam, dan ia-lah yang pertama2 ghazi dengan segala kafir, hingga sendiri-nya berangkat menyerang Melaka.

T. Iskandar (ed.), Bustanu's-Salatan Bab II, Fasal 13 (Kuala Lumpur, 1966), pp. 31-2.

7. The cannon is described in $\mathbf{K}$. C. Krucq, 'Beschrijving der kanonnen afkomstig uit Atjeh, thans in het Koninklijk Militair Invalidenhuis Bronbeek', TBG 81 (1941), pp. 545-6.

8. This has been published only in the form of a shortened Malay prose translation by T. Mohamad Sabil, entitled Hikajat Soeltan Atjeh Marhoem (Soeltan Iskandar Moeda), (Batavia, 1932). H. K. J. Cowan believes the Atjehnese original to be a reworking of the better-known Atjehnese verse epic Hikayat Malem Dagang, with the addition at the beginning of this Turkish incident. De "Hikajat Malěm Dagang" (The Hague, 1937), pp. 12-13.

9. T. Mohamad Sabil, pp. 3-11. 


\section{TURKISH INFLUENCE IN WESTERN INDONESIA}

been recorded more recently from oral traditions. The latter versions, recorded by Snouck Hurgronje in $1891^{10}$ and by Saffet in 1911,11 have the Atjehnese envoys wasting two years in Istanbul rather than at sea. They also stress the existence of a Turkish village in Atjeh named Bitay, which the Atjehnese derive from Bait ul-mukaddis (Jerusalem). Its inhabitants were said to be the descendants of Syrian artisans from that city, who were sent out by the Sultan of Turkey. According to the version of Snouck Hurgronje, the Ottoman Sultan exempted the Atjehnese from sending regular tribute to him as their sovereign. Instead they should honour him by observing the feast of Mohammad's birthday with special zeal. In this way the latter-day Atjehnese explained their exceptional devotion to this Mo'lot feast. Saffet's version also gives a religious character to the authority of the Turkish Caliph. He was alleged to have sent a sermon to be read in the Atjehnese great mosque every Friday.

This oral tradition was strong enough to form an important element in the Atjehnese diplomatic offensive in 1873, when their country was invaded by the Dutch. It even entered briefly into the calculations of the Powers. Atjeh appealed to Turkey for protection on the strength of the ancient connection between the two countries. The Porte took the idea seriously, and stated in an official offer of mediation in the war, communicated to the Netherlands and other Powers:

When Sultan Selim ${ }^{12}$ carried his victorious arms to the extremities of the Arabian peninsula, of which he made the conquest, the echo of his victories reached as far as the island of Sumatra. The Atjehnese sent a deputation to the feet of the conqueror, recognised the supremacy of the powers inherent in his title of Khalif, made an act of submission into the hands of the famous Sinan Pasha, raised the Ottoman flag in their ports and on their vessels, declared themselves vassals of Sultan Selim and asked in return for his high protection. Sultan Selim received these offers favourably. By his orders

10. Snouck Hurgronje, The Achehnese, trans. A. W. S. O'Sullivan (Leiden, 1906), I, 208-9. Also Mohammad Said, Atjeh Sepandjang Abad (Medan, 1961), p. 101. The interpretation of the mission as one of tribute rather than alliance in the version of 1891 may owe something to the events of 1873 , when the Atjehnese attempted to portray their country as under Turkish suzerainty.

11. Saffet Bey, 'Bir Osmanli Filosunun Sumatra Seferi', Tarihi Osmani Encümeni Mecmuasi 11 (1912), pp. 681-3. See Appendix for this material.

12. Sultan Selim I (1512-20) seems to be meant here. He conquered Egypt in 1517 and received as a result the submission of the Hejaz. If so it must be the result of a confusion with Selim II (1566-78), under whom the contact did take place, and the Yemen was reconquered (see below, pp. 16-17). A Turkish newspaper of 1873 similarly attributed it to Selim I; see R. H. Djajadiningrat, 'Critisch Overzicht van de in Maleische Werken Vervatte Gegevens over de Geschiedenis van het Soeltanaat van Atjeh', BKI 65 (1911), p. 146. Curiously, K. C. Krucq, op. cit. p. 546, appears to have made the same mistake. 


\section{TURKISH INFLUENCE IN WESTERN INDONESIA}

the Vezir Sinan Pasha sent to the vassal Sultan the cannons and swords of honour which are still to be seen in Atjeh. ${ }^{13}$

While the date of the mission thus seems to have been pushed back by the Turks to a period before Atjeh's appearance on the international scene, other Atjehnese accounts prefer to credit it to the reign of the great Iskandar Muda. But the mission takes on different shapes to suit the chronicler's purpose. Thus the Hikayat Atjeh, a hymn of praise to Iskandar Muda written during his lifetime, makes the incident an opportunity to show how "the account of Djohan Alam [Iskandar Muda] became famous throughout all nations of the earth". ${ }^{14}$ The Turkish incident is made to follow the story of an embassy from Siam, which resulted in the greater glory of Iskandar Muda among the nations of the East. Then a delegation arrived from Rum, via Yemen and Mocha, seeking oriental balms to cure the illness of Sultan Muhammad (Mehmed III, $1595-1603$ ?). The envoys arrived while Iskandar Muda was warring against Deli (thus 1612), but they were splendidly received on his return. Later the envoys reported back to Sultan Rum on the wonders of Atjeh, whereupon the Ottoman ruler declared:

in former times in the providence of God there were two great kings in the world, the prophet Solomon and Raja Iskandar... Now in our time also in the providence of God there are two great kings in the world. In the west we are the great king, and in the east Sri Sultan Perkasa Alam [Iskandar Muda] is the king who is great and who upholds the religion of God and his Prophet. ${ }^{15}$

Later the Pasha of Yeman confirmed the envoys' account of Atjeh from some Atjehnese pilgrims in Medina. It was these hajis who brought back to the great Atjehnese religious teacher Sheikh Shamsud-din of Pasai the story of all that had occurred in Turkey. ${ }^{16}$

For a yet more fanciful account we might turn to the ever-popular Malay romance of Hang Tuah. This legendary hero of the last years of the Malacca Sultanate is pictured on a variety of adventurous missions for his Sultan. After visits to Majapahit, India and China, he is finally sent to Rum to buy cannons for Malacca. Though much embroidered, the basic story may well be borrowed from the Bustanu's-Salatin. ${ }^{17}$

Thus the notion that diplomatic relations were established with Turkey, and cannons received in exchange for tribute, is well

13. Rashid (Turkish Foreign Minister) to Musurus (Ambassador to Britain and the Netherlands) 11 Aug. 1873, Woltring (ed.), Bescheiden Betreffende de Buitenlandse Politiek van Nederland, 2de Periode (The Haguc, 1962), I, 612.

14. T. Iskandar (ed.) 'De Hikajat Atjeh', VKI XXVI (The Hague, 1958), p. 167 (p. 239 of MS).

15. Ibid. p. 167 (p. 238 of MS).

16. Ibid. pp. $62-4$ and $157-69$ (pp. 215-42 of MS). Also Djajadiningrat, pp. 177-8.

17. Hikajat Hang Toeah (2nd ed. Balai Pustaka, Batavia, 1948), II, 237-87. 


\section{TURKISH INFLUENCE IN WESTERN INDONESIA}

established in the indigenous literature. Of the sources mentioned, the Bustanu's-Salatin is much the most reliable in matters of chronology. It would therefore be reasonable on the basis of the Indonesian materials alone to assume that a relationship of this type was established during the reign of Sultan Alau'd-din Ri'ayat Shah al-Kahar (1537? - 1571), and that this became the basis for differently dated stories in the other sources. As Professor B'oxer's article makes abundantly clear, the Portuguese (as well as Turkish) sources regarding this contact also focus almost exclusively on the reign of al-Kahar.

It seems to the writer that the Portuguese material systematically presented for the first time by Professor Boxer lends further support to an interpretation giving to Turkey a substantial role in the fortunes and alliances of the Muslim states of Southeast Asia during the sixteenth century. What follows is an attempt to relate some Southeast Asian developments to the wider sphere of Turkish and Islamic politics.

Atjeh first emerged as a strong local power by the conquest of Daja to the West (1520) and Pidië and Pasai to the East (1521 and 1524) during the reign of Sultan Ali Mughayat Shah (1516? - 1530). The two latter conquests involved the defeat of substantial Portuguese forces, and made North Sumatra safe from the Western challenge for several centuries to come. Atjehnese power during this early period rested in large part on weapons captured from the Portuguese, and probably also on the support of the Muslim commercial element from the old trading centres of Pasai and P'idië. But Atjeh was not yet in a position to threaten overseas enemies such as Portuguese Malacca. The relatively inactive decade following the capture of Pasai may have been a period of consolidation, or of internal dispute under Salah-ad-din (1530-37?) - “a weakling, not fit to rule", according to Malay sources. ${ }^{18}$

Meanwhile Muslim trade in the Indian Ocean was recovering from the Portuguese onslaught, which had incapacitated it almost completely during the first two decades of the century. ${ }^{19}$ The date 1534 given by Boxer, ${ }^{20}$ or "a few years" after 1526 by MeilinkRoelofsz, ${ }^{21}$ for the first documented Atjehnese pepper-shipment to the Red Sea forms the background to a new burst of expansion in the late 1530's. It seems more than likely that the Muslim shipping of this period was centred not at Banda Atjeh, the capital of the

18. Djajadiningrat, p. 152.

19. Donald Lach, Asia and the Making of Europe, I, ii, p. 107. R. B. Serjeant, The Portuguese off the South Arabian Coast, Hadrami Chronicles (Oxford, 1963), p. 14.

20. Infra, p. 416.

21. M. A. P. Meilink-Roelofsz, Asian Trade and European Influence in the Indonesian Archipelago between 1500 and about 1630 (The Hague, 1962), p. 145. 


\section{TURKISH INFLUENCE IN WESTERN INDONESIA}

weak Salah-ad-din, but at Pasai, where his energetic brother Ala'addin (later Sultan) held local authority. ${ }^{22}$ The valley of the Atjeh river, behind Banda Atjeh, had never produced much pepper, the cultivation of which had long been centred in Pasai and Pidië. Pinto's reference to a treaty giving the Turks a factory at Pasai about $1540^{23}$ is evidence that the trade continued to be centred there for some time after the shift of the political centre. If the first Atjehnese attack on Malacca, in 1537, predated Ala'ad-din's assumption of the throne, it is likely that the expedition was nevertheless launched by Ala'ad-din from Pasai.

The exact date of Ala'ad-din's overthrow of his elder brother is unclear, though it cannot be later than 1539 and may have been as early as 1537.24 The events leading up to this coup and the beginning of a more energetic period of expansion thus coincide with the major Turkish enterprise in the Indian Ocean - Sulaiman Pasha's abortive expedition to Diu in 1537-8.

Following Pinto's account, ${ }^{25}$ the major antagonist of Atjeh during the late 1530's would have been an extensive Batak state which had access to the north as well as the west coast of Atjen, but whose centre was probably in the region of the Singkil river (the stillBatak area of Tapanuli). The warfare between Atjeh and the Bataks turned in favour of the former only after

there came to the Tyrant [Ala'ad-din] 300 Turks, whom he had long expected from the Streight of Mecqua, and for them had sent four vessels laden with pepper.

These hardy warriors with their up-to-date arms enabled Atjeh to drive the beseiging Bataks back to the hills with considerable losses. A Batak emissary was thereupon sent for help to Malacca, where he awaited the new Governor de Faria and Pinto in June, 1539. ${ }^{26}$

This first recorded instance of substantial Turkish help for Atjeh must have taken place sometime in 1537 or 1538 . Thus either just before or just after the great Turkish attempt to smash the Portuguese fleet under Suleiman Pasha, Governor of Egypt. We know that Suleiman despatched envoys to Gujerat and the Arabian ports in 1537 to gain their support for the attack on the Portuguese. ${ }^{27}$

22. Iskandar, 'De Hikajat Atjeh', p. 38.

23. Infra, p. 403.

24. Iskandar, loc. cit. Djajadiningrat, pp. 152-3.

25. Pinto's unreliability has been demonstrated in the case of his supposed ardventures in Siam and elsewhere, but not for matters in Sumatra which were of more immediate concern to his probable informers in Malacca. His account is confirmed in general terms by some other Portuguese references (v. MacGregor, in JMBRAS 28, ii, p. 82) and has been consistently followed by historians of the area.

26. The Voyages and Adventures of Ferdinand Mendez Pinto, the Portuguese trans. H. Cogan, introd. A. Vamberry (London, 1891), pp. 31-2.

27. Serjeant, pp. 76-7 and 79-80. E. Denison Ross, "The Portuguese in India and Arabia $1517-1538$, JRAS 1922, p. 15. 


\section{TURKISH INFLUENCE IN WESTERN INDONESIA}

Did he also send envoys to Atjeh, which must have been well known to him from its pepper shipments? If so, this might have served as a stimulus for the first Atjehnese attack on Malacca in September 1537, and also for a correspondence between Johor and Atjeh in the autumn of 1538 about a joint attack on the infidels at Malacca. ${ }^{28}$ It might, on the other hand, be argued that the Turkish troops noted by Pinto were a more fortuitous windfall for Atjeh from Sulaiman Pasha's unwieldy army of 20,000, many of whom "dispersed because the people of India had induced them away" during their abortive siege of Diu in September, 1538..$^{29}$ In that case the dating of the events described by Pinto would have to be compressed into a few months preceding his arrival in Malacca. Whatever the dating, it also seems likely that the Turkish contact may have provided legitimation in Ala'ad-din's eyes for his seizure of the throne from his elder brother.

The utter defeat of the 1538 expedition and his own inability to control his agents so far away must have decided the 'Grand Turk', Sultan Suleiman the Magnificent, to concentrate his major designs on Europe. Later Turkish initiatives in the Indian Ocean were of very minor significance, with the possible exception of the fleet of Piri Bey, smashed by the Portuguese in the Persian Gulf in $1551 .{ }^{30}$

In Atjeh itself the influx of Turkish men and weapons enabled Ala'ad-din Ri'ayat Shah al-Kahar to defeat the Bataks and then to turn his forces against Aru, a once-mighty state in northeastern Sumatra. In this he was again successful, according to Pinto's account, because of the continued receipt of Turkish soldiers and weapons from Egypt. One of Atjeh's war-leaders, Pinto recounts, was an Abyssinian called "Mamedecan",

who a meneth (or thereabout) before was come from Juda [Jidda], to confirm the new league made by the Bassa of Caire, on the behalf of the Grand Signior, with the Tyrant of Achem whereby he granted him a custom house in the Port of Pazem [Pasai]. ${ }^{31}$

Shortly afterward, however, probably still during 1540, the Atjehnese were expelled from Aru by a combined force of Malays from Johor, Riau, Siak, Perak and elsewhere led by the Sultan of Johor, who had married the widow of the slain ruler of Aru. In the course of the battles of 1540 for possession of Aru most of the Turkish elite troops on the Atjehnese side appear to have perished. ${ }^{32}$ Thus once again, Atjeh's expansion was halted. During the 1540's

28. I. A. Macgregor, 'Johore Lama in the Sixteenth Century', JMBRAS 28 ii. p. 81.

29. Hadhrami chronicle al-Sana al-Bahir, quoted Serjeant, p. 97.

30. M. Longworth Dames, 'The Portuguese and Turks in the Indian Ocean in the Sixtecnth Century', JRAS 1921.

31. Pinto, p. 63.

32. Ibid., pp. 62-76. 


\section{TURKISH INFLUENCE IN WESTERN INDONESIA}

and 50's we hear less of Sultan Ala'ad-din al-Kahar, whose main concern appears to have reverted to strengthening his economic position as the major supplier of pepper for the Muslim trade. P'epper growing spread down the west coast of Sumatra to the south of Minangkabau, and Atjeh's commercial control followed with it.

The only major blow by Atjeh against the Christian intruders during this period was an attack on Malacca in 1547, but this was not large by Atjehnese standards. A detachment of Turks was again noted among the assailants, but the Portuguese chroniclers do not mention any specific alliance. These Turks may be explained in the context of the steadily-expanding numbers of traders from the Red Sea who must have been calling at Atjeh during the period.

Indeed it was the ruler of Johor, rather than Atjeh, who appeared to the Malacca Portuguese as "the man most feared in this fortress", or "our capital enemy" during these two decades.33 The sources do not provide evidence that the forces of international Islam began to look to Johor to rally their eastern flank. But on a local level Johor did take this role upon itself. In 1550-51 it organised an anti-Portuguese coalition in the name of Islam, which included Japara, Portugal's main rival in the Moluccan spice trade, as well as the smaller Malay states of the Peninsula. ${ }^{34}$

The 1560s, on the other hand, saw Atjeh suddenly re-emerging as the formidable eastern bastion of the Muslim counter-crusade against the Portuguese. Professor Boxer's paper warns us against seeing this political connnection as the result of a wholly new commercial link with the Red Sea ports. The 1560's were merely the peak period for a trade which had steadily been gathering strength at the expense of the Portuguese since the 1530's. Its growth is explained in part by the increasing volume and strength of Gujerati and Arab shipping in the Indian Ocean in relation to the Portuguese. In part, also, it relates to events in Indonesia. By the 1560's the rich new pepper-plantations must have been established around Tiku, Pariaman and Indrapuri on Sumatra's west coast, and brought under Atjehnese control. ${ }^{35}$ Moreover the Muslim merchants of

33. Macgregor, pp. 84-5, quoting respectively Simao de Mello, 1545, and Luis Frois, S.J., 1555.

34. H. J. de Graaf, 'De Regering van Panembahan Senapati Ingalaga', VKI XIII (1954), pp. 33-4; P. A. Tiele, 'De Europeërs in den Maleischen Archipel', $B K I$ 28 (1880), p. 321, Meilink-Roelofsz, p. 149. The main source for all these references is again Couto.

35. At Ala'ad-din al-Kahar's death in 1571, and probably for some time previously, his son Raja Mughal was established as Atjehnese viceroy in Pariaman. Judging by 18 th and 19th Century experience, Atjehnese methods of growing pepper on virgin soil began to produce diminishing returns within less than a century as a result of soil exhaustion (v. especially J. Gould 'Sumatra - America's Pepperpot, 1784-1873' Essex Institute, Historical Collections 122 (1956), pp. 207-39 and 297-319). The old centres of Pidië and Pasai, still at their peak 


\section{TURKISH INFLUENCE IN WESTERN INDONESIA}

Japara and Banda were steadily eroding Portuguese control of the Moluccan spice trade, especially since the 1550's. Much of their spice was carried to the West through Atjeh.

While, therefore, we can safely assume the existence of a stable and expanding commercial connection between Turkey and Atjeh from 1540 onwards, the evidence for political connections is markedly discontinuous. Throughout the 1560's there are Portuguese, Turkish or Venetian references to political relations between the two countries, where there had been silence for the two previous decades.

Of the three sources of information, the Turkish are the most important and specific. They include a few letters from Sultan Selim II dated 1567-8 about a planned expedition to Sumatra. The first, dated 16 Rabi'ul-awal 975H (20 Sept. 1567), was Selim's lengthy reply to the embassy of Sultan Ala'ad-din Ri'ayat Shah al-Kahar. It describes how the Atjehnese envoy, Husain, had requested help against the kafirs, who had been harrassing traders between Mecca and Sumatra, and oppressing Muslims in Calicut and Ceylon as well as the Sumatran area. Selim had decided to grant the request for aid, by sending a fleet of 15 galleys and 2 barks, with numerous master gunsmiths, soldiers, and artillery. The Admiral of Suez, Kurtoglu Hizir Reis, was instructed to command the fleet, to crush Atjeh's enemies, and to take the 'old fortress' from the hands of the kafir. This letter was sent to Ala'ad-din by the hand of a Turkish envoy, Mustaffa Camus. ${ }^{36}$

Another letter of approximately the same date give instructions to Kurtoglu Hizir about the expedition. Salaries and provisions for the men would be provided for a year, after which the Sultan of Atjeh would have to support them if he still required them. ${ }^{37}$

Four months later, on 5 Rajab $975 \mathrm{H}$ (5 Jan. 1568), Selim wrote to the Atjehnese envoy Husain. He regretted the Sumatra campaign had had to be delayed because of a rebellion in the Yemen, which the fleet of Kurtoglu Hizir had been diverted to suppress. God willing the rebellion would be crushed, and the expedition to Sumatra would take place "next year" [i.e. the Hijra year 976 begimning June 1568$]^{.38}$

Beyond this the primary sources do not go. We know much about the suppression of the Yemen revolt, finally completed by

in Tomé l'ires' time, were unimportant by the end of the century. We may, therefore, suggest a shift in the centre of pepper-growing sometime in the middle decades of the sixtecnth century with the rapid growth of the west coast plantations.

36. Saffet Bey, 'Bir Osmanli Filosunun Sumatra Seferi', TOEM 10 (1912), pp. 606-9. Sce appendix to this paper for the Turkish materials.

37. Saffet, op. cit. 11 (1912), p. 680.

38. Ibid. loc cit. 


\section{TURKISH INFLUENCE IN WESTERN INDONESIA}

Sinan Pasha in 1571. But it is only the Atjehnese and Portuguese sources which give us grounds for thinking that at least the large cannon and the gunsmiths sent out by Selim must have reached Atjeh, and possibly a few of the ships. This cannot, however, have been in time for the major Atjehnese attack on Malacca which lasted from 20 January to 25 February 1568.

The Western sources, on the other hand, suggest a much earlier military alliance between Atjeh and Turkey. In particular the Venetian ambassador to Constantinople reported as early as June 1562 that an Atjehnese ambassador was in the city to ask for artillery to fight the Portuguese. ${ }^{39}$ In 1564 Venetian sources already stated that Turkey had sent arms and gunners to Atjeh. ${ }^{40}$ This earlier dating receives a little support from the story of the sea-battle off the South Arabian coast in March-April 1561. According to Couto's version of this, the large ship from Atjeh which the Portuguese attacked was laden with gold and jewelry for the Sultan of Turkey - a possible indication that the Atjehnese were anxious to negotiate with him. ${ }^{41}$

The Portuguese sources are less specific as to chronology. The most quoted is Couto's Capitulo 21 of Decada VIII, which describes the preparations of Sultan 'Alabaradi' to take Malacca. He sent rich presents to the Grand Turk, and promises of all the spices of the Indonesian region once Malacca was back in Muslim hands. The Ottoman Sultan responded immediately to his request for aid, sending "500 Turks, many large bombards, abundant ammunition, many engineers and masters of artillery". Other Atjehnese ambassadors were sent to 'Baroche' [Bijapur?], Demak, Calicut, and the Coromandel coast rulers seeking assistance. All sent help except Demak, which was so afraid of the insatiable ambition of the Sultan of Atjeh that it put his ambassadors to death.

All this, Couto continues, was communicated to the Viceroy Antonio Noronha when he assumed office in 1564. He immediately ordered reinforcements for the Malacca fortress to defend it against the Atjehnese. Couto then immediately continues, in the following chapter, to relate the major Atjehnese attack of $1568 .{ }^{42}$ It may therefore be reading too literally to assume all the preparations attributed by him to Atjeh took place before 1564.43 Rather may

39. Von Hammer, cited in Denys Lombard, Le Sultanat d'Atjeh au temps d'Iskandar Muda (Paris, 1967), p. 37n.

40. Tiele, op. cit. p. 424.

41. Boxer, infra, p. 418, Serjeant, p. 110.

42. Diogo De Couto, Da Asia (Lisbon, 1786) VIII, caps. 21 and 22.

43. As issumed by Tiele, op. cit. p. 425; De Graaf, p. 68; Djajadiningrat, p. 155; Meilink-Roclofsz, p. 149, and Professor Boxer, infra, p. 420. My doubt is strength. ened by Couto's introduction to his account of Atjehnese plans, which states that after mastering Pedir, Pasai and Aru, only Malacca stood in his way to becoming emperor of the Malays. The conquest of Aru and Johor are usually dated in 1564 . 


\section{TURKISH INFLUENCE IN WESTERN INDONESIA}

we assume that they were the preparations for the 1568 attack, but were sufficiently apparent already in 1564 to alarm Noronha.

Couto is certainly not alone in referring to Turkey's help for Atjeh earlier than 1568. According to Jesuit sources, a Turkish ambassador was in Atjeh when some Portuguese vessels arrived there to trade during 1565. Although Atjeh had previously not been at war with Malacca, the intervention of the Turk resulted in the Portuguese being given the choice of conversion to Islam or martyrdom. ${ }^{4+}$ The same Jesuit letters, written in Malacca at the end of 1566, indicate that an attack on Malacca was expected, and that men and artillery for it had been supplied from Turkey, "for the Turks merchandise with this king, who, every year, sends him many loaded vessels to Mecca". ${ }^{45}$

Couto is quite clear that during the attack of January - February 1568 the Atjehnese were aided by about 400 Turks, as well as some help from Japara and Calicut. But the Jesuits insist that Turkish assistance to Atjeh continued after the failure of that attack. A letter from Malacca at the end of 1568 reported that the Malaccans were still living in fear, because the Sultan of Atjeh was continuing his warlike preparations, and his alliances with Muslims in India, Malaya and Java. Because of his great commerce with Turkey, "the Turk provides him with men, gunners and artillery with which he makes war against us". ${ }^{46}$ This pressure was maintained, and gave the Portuguese some of their most anxious moments in Asia, until in 1570-71 Bijapur, Ahmadnegar (Gujerat), Calicut and Atjeh launched a concerted offensive against Portuguese possessions. This offensive was halted in a series of notable battles, particularly at Malacca on 21 st October, 1570. ${ }^{47}$

Combining our various sources, the following reconstruction of the events of the 1560's appears the most probable. The growing commerce between the Red Sea and Sumatra must have brought a steady trickle of Turkish traders and adventurers to Atjeh, whose military expertise often proved useful to Atjeh. The Portuguese attacks against this commerce from 1554 encouraged plans for larger scale attacks against the Portuguese menace. From as early as 1561-2 Atjeh was sending envoys to Constantinople to procure supplies and men, and to try to interest the Ottoman Sultan in a major military operation. These efforts must have succeeded in

44. Letters of L. Peres, Malacca, November and 2 December, 1566, in J. Wicki (ed.), Documenta Indica VII (MHSI 89, Rome, 1962), pp. 33-4 and 89. Tiele, pp. 425-6, doubts the validity of this story, but he has it only from a secondary Jesuit source.

45. Wicki, p. 88.

46. Letter of C. da Costa, Malacca, 6 Dec. 1868, Wicki, op. cit. pp. 529-30. Also ibid. pp. 514-5, and 574-5.

47. Wicki, Documenta Indica VIII (MHSI 91, Rome, 1964), pp. 488-9. F. C. Danvers, The Portuguese in India (London, 1894), I, pp. 551-571. 


\section{TURKISH INFIUUENCE IN WESTERN INDONESIA}

obtaining substantial reinforcements of Turkish mercenaries at least by 1568 , and probably as early as 1564 , when they may have helped Atjeh to make a military comeback by conquering Aru and Johor. Some arms were probably also purchased. There may even have been some official Turkish response about the period 1564-6, though probably not at the level of the Sultan himself. The Atjehnese embassy of Husain, which probably covered the years 1565-8, achieved much more spectacular success. After the delay caused by the death of Sulaiman in 1566, Selim II was sufficiently impressed by the opportunities in the Indian Ocean to decree a major expedition. His decision, taken in the autumn of 1567 soon after he had established himself in power, is notable as marking a change of direction for Turkish policy. The decision must have reached Atjeh well before the end of 1567, and produced immediate preparations for an attack on Malacca. On January 20th the attack began without the expected Turkish fleet, probably because Ala'addin had already heard the bad news that Kurtoglu Hizir had been diverted to Yemen, but could not delay his own plans once the preparations for an attack had been finalised.

Kurtoglu Hizir and his fleet never reached Atjeh. But the importance the Atjehnese give to the cannons, the flag, and the gunsmiths makes it reasonably certain that these at least were sent, along with some sort of imperial mesage. They probably reached Atjeh during 1568 or 1569 , and strengthened her considerably in relation to her Indonesian rivals. They must also have encourage further thoughts of a pan-Islamic front against the Portuguese, which had its culmination in the manoevres of 1570-1.

The burst of Islamic solidarity with Indian states soon faded, but its effects in the Indonesian region were felt for another decade. Indeed the death of Ala'ad-din Ri'ayat Shah al-Kahar in 1571 appears to have reduced some of the fears of Atjeh among her neighbours. His successor Ali Riayat Shah (1571-8) showed a more genuine desire to win Johor round to an alliance against the kafirs. It was probably in the early 1570's that he sent one of the great cannons he had received from Turkey to Johor to symbolise this Alliance. ${ }^{48}$ In 1573 Atjeh appealed successfully to the militant Queen of Japara for a joint attack on Malacca, which took place in stages during 1573 and 1574. The Japara fleet arrived before Malacca only after the Atjehnese had retired. Johor too played a supporting role in this alliance, as the Japara ships were reported

48. The Voyage of John Huyghen van Linschoten to the East Indies (Hakluyt, London, 1885y I, p. 110 . Linschoten's wonder at the size of this cannon, "hardly to be found in all Christendom", is echoed in numerous contemporary European descriptions of Turkish artillery. For the anachronistic Turkish preoccupation with size rather than efficiency in their cannons, sec C. M. Cipolla, Guns and ships in the Early Phase of European Expansion (London, 1965) pp. 93-9. 


\section{TURKISH INFLUENCE IN WESTERN INDONESIA}

to have called there on their way to the attack.49 $\quad$ The alliance with Johor appears to have flourished thereafter for the remainder of Ali Riayat Shah's reign in Atjeh. According to one Portuguese account it was sealed by a royal marriage between the ruling houses. ${ }^{50}$

The two decades from 1560 to 1580 must be seen as the highest point for the military fortunes of Islam in Southeast Asia. During this period the Portuguese were consistently on the defensive. Atjeh dominated the Straits of Malacca, with fitful support from Johor and Japara, while the Muslim traders of Japara, Grisek, Ternate and the Banda islands gained the upper hand in the eastern archipelago. How much weight should we give to Turkish intervention in bringing about this greater militance and cohesion on the part of the Muslim states?

The failure of the Muslim powers to unite in the sixteenth century has been much discussed. It should not, however, surprise us. There were no precedents in Southeast Asia, and few in the Muslim world, for states to undertake a joint enterprise on a basis of mutual equality and respect. ${ }^{50 a}$ Boundaries were not clearly defined, and the strongest states were influenced by notions of universal empire inherited from the older Indianised states. Given in addition the basic commercial rivalry of many of the states, it is small wonder that the ambitions of the strong were always suspect.

More remarkable than this background of disunity, it seems to me, are the tentative ventures that were made during the 1560's and 1570 's towards a Muslim alliance. Islam was the only basis for such an alliance. And we must not forget that the political unity of Islam is a doctrine deep-rooted in scripture and history, however distant from practice. Nineteenth century evidence supports the conclusion that the ideal of the Caliphate had particular weight for otherwise disunited Muslims in Southeast Asia. The Malay literature suggests that this was no less strong in the sixteenth century. At a point in time when the illustrious name of Rum and the prestige of the Caliphate were supported by the immense military power of Suleiman the Magnificent, the possibility of a common crusade under Turkish leadership need not have seemed absurd.

Of course we should not press this too far. The only Muslim powers in Southeast Asia which appeared susceptible to the panIslamic ideal were Atjeh, Japara, Ternate, Grisek, and to some extent Johor. As Mrs. Meilink has reminded us, these were all

49. De Graaf, pp. 34-5. Macgregor, p. 86.

50. Macgregor, pp. 86-8.

50a. Such relationships were known only among petty pre-Muslim states in adjacent areas, particularly in 16th Century South Celebes. See G. J. Resink, Indonesia's History Between the Myths (The Hague, 1967), p. 201. 


\section{TURKISH INFLUENCF IN WESTERN INDONESIA}

states which participated in the Muslim spice trade from Ternate through Java and Atjeh to the West. Consequently they shared the international currents of the Muslim world.

It was otherwise with the agrarian heartland of Java, whether this was centred politically at Demak, Pajang, or Mataram. Except for a brief phase under Demak at the beginning of the sixteenth century, this region was economically and culturally more selfsufficient. Bantam, however, is an odder omission from the list of Muslim allies. Founded by the crusading Falatehan, who had left his native Pasai in protest against Portuguese control there, it remained a part of the cosmopolitan Muslim maritime world. Yet like Brunei and a few smaller states it was seldom at odds with the Portuguese. This must be attributed to commercial rivalries with Atjeh. Both attempted to monopolise the supply of pepper, and competed for control of south-west Sumatra. Probably because of Atjeh's obstructionism in the West, Bantam seems to have sent most of its pepper to China and Portuguese Malacca. ${ }^{51}$

If we accept the importance of Turkish intervention on Southeast Asian alliances, should we agree with the Jesuit who argued that the Sultan of Atjeh was "vehemently opposed to all Christians, spurred on to this by the Turks"?52 The above account would lead rather to the conclusion that the initiative for Turkish alliance was taken first by the Atjehnese. During the early 1560's Sultan Suleiman was fully occupied with his push to the west, and can have had little thought of eastern adventure. Indeed it seems possible to argue that it was precisely this Atjehnese initiative which drew Turkish attention once more to the Indian Ocean, after Suleiman had abandoned it in 1540. A recent historian of Ottoman expansion has suggested 1570 as a date when the abler Turkish statesmen were considering a shift in emphasis from the Mediterranean in view of the newly-realised importance of oceanic strategy..$^{53}$ But even before this, in 1568, Selim had issued the remarkable instruction to the Governor of Egypt to prepare a scheme for a waterway between the Mediterranean and the Red Sea.54 Following hard upon the decision in favour of an Atjeh expedition, this indicates the importance placed by Selim's advisers on establishing their naval power in the Indian Ocean.

This new-found emphasis came to naught because it coincided

51. A clear example of this rivalry appears from the Turkish merchant the Dutch encountered in Bantam in 1596, who was unable to return through Atjeh because the Sultan was seizing all traders who came from Bantam. J. C. van Leur, Indonesian Trade and Society (The Hague, 1955), pp. 3-4.

52. Letter of De Ribera (Macau), October 1568, in Wicki VII, p. 514.

53. W. E. D. Allen, Problems of Turkish Power in the Sixteenth Century (London, 1930), p. 30.

54. I. H. Uzuncarsili, Osmanli Tarihi III/i (Ankara, 1951), pp. 31-3. 


\section{TURKISH INFLUENCE IN WESTERN INDONESIA}

with the beginning of the decline in Turkish power. Suleiman was the last of the really masterful Ottomans. The empire was kept in order for a considerable time after his death in 1566 by the talented ministers he had gathered around him - especially the Vezir Sokolli. At the latter's death in 1578 the empire became a prey to weakness and corruption at the centre, leaving the Janissaires as the effective power. ${ }^{55}$ The last Turkish enterprise in the Indian Ocean was the very individualistic one of Ali Beg (1580-9) who relied more on bluff than power in gaining brief recognition from a number of East African states. His capture by the Portuguese in 1589 ended Ottoman naval power east of Aden..$^{56}$ The deterioration of Ottoman power in the Yemen, complete by 1635 , removed even the base from which earlier fleets had set out.

In Atjeh, too, a period of weakness was inaugurated by the death of Sultan Ali Ri'ayat Shah in June, 1578. After a rapid succession of three rulers, Ala'ad-din Mansur Shah was called from Perak to assume a more shaky throne, and was not well obeyed by his new subjects, according to a Portuguese source..$^{57}$ The alliance with Johor collapsed, and war had broken out again by 1582 . The Portuguese could again rely on the passive support of one or the other of their Muslim neighbours.

In India too, the Portuguese were able to establish cordial relations with the Moghul ports in Gujerat towards the end of the century, and to dominate even more the trade of the western Indian ocean. The traffic in Gujerati ships between Atjeh and the Red Sea evidently survived as late as $1598 . .5$ With the coming of English and Dutch shipping to Atjeh, however, it quickly dwindled. In their dealings with Atjeh both Britain and Holland were careful to stress their opposition to Spain/Portugal, and their friendship with Turkey. ${ }^{59}$ Thus the simple opposition between the forces of Islam and the 'Franks' which had been fought for a century on so many fronts, no longer met the needs of the period.

Though the political link with Turkey appears to have been almost completely broken after 1580, Atjeh at least retained a measure of Turkish influence for some time to come. This was most notable in the military field. Atjehnese military tactics, military engineering, and artillery were famous long after their Turkish tutors had departed. An example was their capture of Deli in 1612 by the use of trenches, even though the town was skillfully defended

55. E. S. Creasy, History of the Ottoman Turks (London, 1878', pp. 224-5.

56. Allen, pp. 32-3. Longworth Dames, JRAS 1921, pp. 25-8.

57. Macgregor, p. 88. Iskandar, p. 39.

58. Boxer, infra, pp. 427-28.

59. The Voyages of Sir James Lancaster to Brazil and the East Indies 1591-1603 (Hakluyt, London, 1940), pp. 94-5, and 97-8. The Voyages and Works of John Davis the Navigator (Hakluyt, London, 1880), pp. 142-3. 


\section{TURKISH INFLUENGE IN WESTERN INDONESIA}

by the P'ortuguese. ${ }^{60}$ The palace guard maintained by Iskandar Muda (1607-36) was remarkably similar to the Turkish body of Janisseries. It was composed of military slaves, captured from the enemy when young and trained rigorously in the arts of war. ${ }^{61}$

The control of these considerable military resources on the Turkish model, placed Atjehnese rulers on a perilous pinnacle of power. They were in a position to tyrannise over their subjects to a greater degree than most Indonesian rulers. In the case of Iskandar Muda in particular, the picture we have of a court riddled with suspicion and intrigue, of a closely-guarded palace reserved for the numerous royal women, is more reminiscent of a MiddleEastern state than the more patriarchal style of Indonesian sultanates. It was clearly force, rather than the proverbial loyalty of the Malay, which kept the Atjehnese state together. ${ }^{62}$

Culturally too, Atjeh retained a closer contact with the Muslim countries of the West - though here it was the Arabs rather than the Turks who had something to offer. From the 1570 s the chronicles are dotted with the names of eminent theologians from Egypt, the Hejaz, Yemen and Gujerat who had come to teach in Atjeh. ${ }^{63}$ Schools flourished, and a knowledge of Arabic was widespread among the upper classes. Many of Atjeh's diplomatic letters in the early seventeenth century appear to have been written in Arabic, including the one sent to Queen Elizabeth with Lancaster. ${ }^{64}$

To conclude, then, it is possible to discern two distinct periods at which Turkish intervention was significant in Southeast Asia. The first took place in connection with Suleiman Pasha's expedition to Gujerat in 1538; the second during the peak of the commercial contact with the Red Sea in the 1560's. In both cases Turkish influence was applied through, and to the benefit of, Sultan Ala'addin al-Kahar. But in both cases, and particularly the second, this encouraged an unusual degree of cooperation among some Muslim states of Southeast Asia. The diplomatic contact of the 1560's between Turkey and Atjeh reached the highest level, and was important in the subsequent direction of both Turkish and Atjehnese policy. It has been commemorated in a variety of forms in Malay and Atjehnese literature.

60. Beaulieu, 'Voyage to the East Indies', in John Harris (ed.), Navigantium atque Itinerarium Bibliotheca (London, 1705) I, p. 250.

61. Ibid. p. 251.

62. See especially ibid. pp. 251-5.

63. Djajadiningrat, pp. 160-1.

64. Lancaster, pp. 96 and 109-11. 


\section{TURKISH INFLUENCE IN WESTERN INDONESIA}

\section{APPENDIX \\ Some Turkish Sources for the 'Sumatra Expedition'}

The existence of Turkish references to the 'Sumatra expedition' of the 1560's was first brought to the attention of Southeast Asian historians by the article by Juynboll and Voorhoeve in the new edition of Encyclopedia of Islam. ${ }^{1}$ Unfortunately the effect of condensation and the misprint in the conversion of the only Muslim date given make it in some respects a misleading reference. Salih Ozbaran of SOAS and the University of Istanbul was patient enough to go through some of the Turkish articles with me providing a rough translation. As few Southeast Asian historians have a knowledge of Turkish it may be useful to expand here on the content of the various sources. I am very grateful to Mr. Ozbaran, and also to Prof. Bernard Lewis, for the help they have given.

Much the most important source is an article by the naval historian Saffet Bey, which appeared in two parts in the standard journal of Ottoman history during 1912.2 Though not in scholarly form, it is based on some letters in the Ottoman archives as well as some published sources available to him. The article begins by retelling the lada sa-chupak story from 'European sources' - which can hardly be other than the English translation of Snouck Hurgronje's The Achehnese. Saffet then quotes in full the text of Sultan Selim's first firman on the subject, dated 16 Rabi'ul-awal 975 (20 Sept. 1567). The firman first recapitulates the petition of the Atjehnese 'Vezir', Husain. Atjeh, it is claimed, has been left alone to fight the kafirs up till now, and requests the help of Turkey's experienced soldiers. In the regions around Atjeh there are 24,000 islands, whose Muslim inhabitants are oppresed by the kafirs. The Portuguese have also bombarded and taken prisoner merchants trading between Atjeh and Mecca. Furthermore "the kafirs of Calicut and Ceylon" are harming the Muslim inhabitants of those places. Husain believes that an Ottoman fleet in those parts would be able to crush the kafirs. He also requests that gunsmiths be sent to Atjeh, and that orders be given to the governors of Yemen, Aden, Mecca and elsewhere to assist Turkish soldiers on their way to Atjeh. The firman concludes by granting Husain's petition. Fifteen galleys (kadirqa) and two barks (barça) are ordered to proceed from Suez, with a master gunsmith, seven other gunsmiths, some soldiers, cannons, and smaller guns (tüfenk). The High Admiral Kurt Oglu Hizir is given command of the expedition, with orders to crush Atjeh's enemies, to defend the Muslim religion, and

1. Article, 'Atjeh', Encyclopedia of Islam I, p. 743.

2. 'Bir Osmanli Filosunun Sumatra Seferi', Tarihi Osmani Encümeni Mecmuasi 10, pp. 604-14; 11, pp. 678-83. 


\section{TURKISH INFLUENGE IN WESTERN INDONESIA}

to take the old fortress belonging to the kafirs. Kurtoglu should make arrangements for paying the salaries of his men.

The remainder of the first part of Saffet's article is taken up with some comments on this letter, followed by a description of Suleiman Pasha's 1538 expedition and of Turkish-Portuguese relations.

The second part begins with some further comments about the Atjehnese embassy, which appear to be based on some unnamed Turkish books and the evidence of "a man here called Lutfy, who went to India and returned". Saffet states that the Atjehnese ambassador stayed in Istanbul for two years, in a special place for foreign envoys, while Suleiman was away on the Szigetvar campaign. Selim II however welcomed the envoy after his father's death, and sent him on a Turkish vessel to Alexandria. From there he was accompanied to Aden by other Turkish officials. Later the Atjeh expedition was prepared in Suez, consisting of altogether 19 galleys and three barks. Kurdoglu Hizir Reis was to be commander and Mehmet Bey deputy commander. They were to be at the disposal of the Atjehnese Sultan for as long as he required them, though they had salary and provisions for only one year.

To reinforce this last information Saffet quotes two further letters from the Ottoman archives. The first instructed Kurtoglu to besiege the kafirs' fort by land while his deputy Mehmet remained with the ships. The second, dated 5 Rajab 975 (5 January, 1568), advised Sultan Ala'ad-din $\mathrm{Ri}^{\prime}$ ayat Shah that the expedition had been delayed because of the rebellion in Yemen. "God willing the rebellion will be crushed, and the expedition will proceed next year."

These are the only archival sources given. Saffet goes on to describe Kurtoglu's activities in the Yemen, about which, he says, there is abundant literature.

He quotes two later Turkish writers of the mid-seventeenth century who refer to Atjeh. These are the geographers Katib Celebi and Ebu Bekr Dimiskî, in their works respectively entitled Cihannûma and Cografya. They appear to say little about the Atjehnese save that they were good fighters, who had learned how to make guns and swords from the Turks.

Saffet closes his article with two interesting informants of his own time. The first is a member of the Atjehnese royal family who met Saffet in October, 1911, and told him the following story: Long ago Atjehnese ambassadors went to Turkey seeking help. Two ships were sent in return to Atjeh, with many soldiers and craftsmen. The guns and flags from these two ships remained in Atjeh until the war against the Dutch. Neither ships nor men ever 


\section{TURKISH INFLUENCE IN WESTERN INDONESIA}

returned to Turkey. They established a Turkish village in Atjeh, whose inhabitants still regard themselves as Turkish, though they have assimilated completely into the Atjehnese culture. With the two ships there also came a firman, which was still in the hands of the last Raja." There also came with the ships a sermon, subsequently read in the mosque every Friday. There were numerous guns, large and small. A Turkish ambassador named Seyyid el-Kemal was subsequently made commander of an Atjehnese province. Some ulama also came with the ships, among them Sheikh Abdur'rauf, Teungku Kuala. ${ }^{4}$

Finally, Saffet quotes a Turkish traveller, Abdul Aziz, who visited Atjeh in 1898 and met the ulèebalang of Meureudu, Teuku Suleiman. This ulèbalang told him that there was one old Turkish cannon in the Governor's residence, and one in Java. Abdul Aziz related further "I saw in Atjeh a Turkish cemetery and other people resembling Turks, but though they know unfortunately little about Turkey they still say they are Turks. I saw nothing else of interest".

The other Turkish historians who have noted the Atjeh affair appear to rely on Saffet. But what is hypothesis in Saffet's work has become fact for the later writers. I. H. Uzuncarsili, in his standard Osmanli Tarihi, relates that Atjeh sent an embassy to Istanbul in 1565. The ambassador had to wait for two years, until Selim II accepted his appeal and decided to despatch over 20 ships. After the expedition was diverted to Yemen, the equipment and gunsmiths were sent on to Atjeh in two ships. The Turks who were sent to Atjeh setled there.

The nationalist historian Danismend ${ }^{6}$ goes further in asserting. the certainty of the expedition to Atjeh, and does not even mention the diversion of Kurtoglu's fleet to Yemen. He stresses the sovereignty which Selim assumed over Atjeh, and concludes by pointing out that after Ottoman rule expanded to much of Europe, Asia and Africa, it finally reached as far as Atjeh.

3. Tuanku Daud, who resigned the Sultanate in submitting to the Dutch in 1903, and was exiled from Atjeh three years later.

4. Abdur'rauf of Singkil, the national saint of Atjeh. He is known as Teungku Sheikh Kuala because his keramat, or tomb, is at the mouth of the Atjeh river. This linking of his name with the Turkish expedition seems to be gratuitous. D. A. Rinkes, Abdoerraoef van Singkel. Bijdrage tot de kennis van de mystiek op Java en Sumtra (Friesland, 1909).

5. Osmanli Tarihi II (Ankara, 1949), pp. 388-9.

6. I. H. Danismend, Osmanli Tarihi Kronolojisi II (Instanbul, 1948), pp. 380-1. 